IJPDA

ais

âd

\title{
In-vitro screening of antihelmintic and antibacterial activity of malvastrum coromandelianum leaves
}

Tirupathi Rao Annavarapu*1, B Pragna Malavika², Aravinda Swami P1.

${ }^{1}$ SIMS College of Pharmacy, Mangaldas Nagar, Guntur,Andhra Pradesh.

2 NOVA College of Pharmaceutical Education and Research,Jupudi,Andhra Pradesh.

\begin{tabular}{|c|c|}
\hline Article History & Abstract \\
\hline $\begin{array}{l}\text { Received on: 17-11-2020 } \\
\text { Revised On : 28-01-2021 } \\
\text { Accepted on : 04-02-2021 }\end{array}$ & \multirow{3}{*}{$\begin{array}{l}\text { The main objective of the work is to investigate the antithelmintic and antibacterial } \\
\text { activity of the Malvastrum coromandelianum leaves. The extract was tested for } \\
\text { antithelmintic activity against adult Indian earthworm and also tested for } \\
\text { antibacterial activity against the gram positive bacteriaS.aureus,B.subtilis and gram } \\
\text { negative bacteria against E.Coli, P.aerugenosa, P.putida. The anthelmintic activity } \\
\text { was observed at } 100 \mathrm{mg} / \mathrm{ml} \text { with reference to standardAlbendazole }(10 \mathrm{mg} / \mathrm{ml}) \text {.The } \\
\text { maximum antibacterial activity was observed in S.aureus at } 500 \mathrm{mg} / \mathrm{ml} \mathrm{with} \mathrm{of} \mathrm{zone} \\
\text { of inhibition } 17 \mathrm{~mm} \text { and next is S.aureus, the best antibacterial activity was observed } \\
\text { against P.aerugenosa and P.putidawith } 15 \mathrm{~mm} \text { of zone of inhibition. The zone of } \\
\text { inhibition of extract was compared with standard Gentamycin } 25 \mu \mathrm{g} / \mathrm{ml} \text {. The } \\
\text { extract shows significant activity against the other bacterial pathogens. From the } \\
\text { results, it was concluded that the ethanolic extract of Malvastrum coromandelianum } \\
\text { leaves have anthelmintic and antibacterial activity. }\end{array}$} \\
\hline $\begin{array}{l}\text { *Corresponding Author } \\
\text { Tirupathi Rao Annavarapu } \\
\text { SIMS College of Pharmacy } \\
\text { Mobile No: } 9493825355 \\
\text { Email: tirupathionline@gmail.com }\end{array}$ & \\
\hline \multirow[t]{2}{*}{$\begin{array}{l}\text { DOI:https://doi.org/10.47957/ijpda. } \\
\text { v9i1.450 }\end{array}$} & \\
\hline & $\begin{array}{l}\text { Keywords: Antibacterial, Anthelmintic, Malvastrum coromandelianum } \\
\text {,Gentamycin, Albendazole. }\end{array}$ \\
\hline
\end{tabular}

(C) 2021 Published by South Asian Academic Publications. This is an open access article under the CC BY license (https://creativecommons.org/licenses/by/4.0/

\section{Introduction}

Herbs are any plants "with leaves, seeds, or flowers used for flavoring, food, medicine, or perfume" or parts of "such a plant as used in cooking [1]. The plant products are rich in different therapeutic activities like antimicrobial [6-7], antimalarial, antifungal, hepatoprotective, anthelmintic, antioxidant, anticancer, anti-inflammatory etc. Malvastrum coromandelianum is commonly known as false mallow, broom weed, and clock plant. It is belongs to the family of malvaceae. It consists of different chemical constituents like alkaloids, tannins, amino acid proteins, and carbohydrates, with appreciable amounts of phenolic and flavonoid contents. The can be used in treatment of different pathological conditions like ring worm infection [2], jaundice [3], diabetes [4], anti-inflammatory and analgesic [5]. Anthelmintics are the agents used to treat helminthiasis. This leads to health complications in humans and cattle's. The natural agents are more effective for helminthiasis [11] than chemical agent with fewer side effects. Antibacterial agents are the agents which are used to treat different bacterial infections either gram positive or gram negative infections.

\section{Materials And Methods Collection plant material}

The leaf material ofMalvastrum coromandelianum was collected from surroundings of Aditya Pharmacy College,Surampalem, East Godavari, Andhra Pradesh.

\section{Preparation of Extract}

The leaf materials were dried under the shade for 5-7days and ground to fine powder with the help of electrical grinder. The dried powder of leaves of Malvastrum coromandelianum subjected to maceration separately using ethanol for 5days with intermittent shaking. The extract was prepared by maceration of $80 \mathrm{gm}$ of powder with $500 \mathrm{ml}$ ethanol solvent. The obtained liquid is subjected to distillation [12].The extracts thus obtained is then evaporated to dryness and used in present study. 


\section{In- Vitro anthelmintic Activity}

\section{Test Organisms}

Anthelmintic activity; The Healthy adult Indian earthworms Pheritimaposthumadue. These organisms are collected from surrounding of SIMS College of Pharmacy, Guntur. Standard Concentration $(5 \mathrm{mg} / \mathrm{ml}): 1.25 \mathrm{ml}$ of Albendazole suspension was taken and diluted to $10 \mathrm{ml}$ with sodium CMC solution. Test extract concentrations: $1 \mathrm{gm}$ of ethanolic extract was dissolved in $10 \mathrm{ml}$ of sodium CMC which is regarded as (T1) $(100 \mathrm{mg} / \mathrm{ml}), 5 \mathrm{ml}$ of $\mathrm{T} 1$ diluted to $10 \mathrm{ml}$ of sodium CMC which is regarded as (T2) $(50 \mathrm{mg} / \mathrm{ml}) .5 \mathrm{ml}$ of $\mathrm{T} 2$ diluted to $10 \mathrm{ml}$ of sodium CMC which is regarded as (T3) $(25 \mathrm{mg} / \mathrm{ml})$.

\section{Method}

The different concentrations of ethanolic extracts ofMalvastrum coromandelianum were evaluated for anthelmintic activity using adult Indian earthworm model. The anthelmintic assay was carried as per the method[8] with minor modifications. The extracts exhibited a dosedependent inhibition of spontaneous motility (paralysis). The earth worm was placed in petridish containing three different concentrations $(100,50 \& 25 \mathrm{mg} / \mathrm{ml})$ of ethanolic extract of leaves of Malvastrumcoromandelianum. Each petridish was placed with one worms and observed for paralysis or death. Mean time for paralysis was noted when no movement of any sort could be observed, except when the worm was shaken vigorously; the time death of worm ( $\mathrm{min}$ ) was recorded after ascertaining that worms neither moved when shaken nor when given external stimuli. The test results were compared with reference compound Albendazole $(5 \mathrm{mg} / \mathrm{ml})$ treated samples.

\section{In-Vitro Antibacterial Activity}

Antibacterial activity; For this study two gram positive bacteria such as S.aureus,B.subtilis and three gram negative bacteria such as E.Coli, P.aerugenosa, P.putidaare used [9]. These cultures are procured from MicrobesSpeciality Lab Danavaipeta, Rajahmundry,East Godavari District 533103, AndhraPradesh, India. The nutrient agar media was used for antibacterial test. The concentrations of test compounds were prepare by dissolving the dried extract in Sodium CMC at a concentration of $100 \mathrm{mg} / \mathrm{ml}, 300 \mathrm{mg} / \mathrm{ml}$ and $500 \mathrm{mg} / \mathrm{ml}$. The reference standard Gentamycin was prepared at a concentration of $25 \mu \mathrm{g} / \mathrm{ml}$ with same solvent.

\section{Method}

The antibacterial activity of ethanolic extract was performed using Agar cup-plate method [10]. $20 \mathrm{ml}$ of sterile nutrient agar medium was poured into sterile Petridishes and allowed to solidify. The Petri dishes were incubated at $37^{\circ} \mathrm{C}$ for 24 hours to check for sterility. The medium was seeded with the organisms by pour plate method using sterile top agar $(4 \mathrm{ml})$ contained $1 \mathrm{ml}$ culture. Bores were made on the medium using sterile borer. The different concentrations of extract $(100 \mathrm{mg} / \mathrm{ml}$, $300 \mathrm{mg} / \mathrm{ml}$ and $500 \mathrm{mg} / \mathrm{ml})$, were added $(0.05 \mathrm{ml})$ to the respective bores. The standard drug Gentamycin at a concentration of $(25 \mu \mathrm{g} / \mathrm{ml})$ was taken as standard reference. All the plates were kept in a refrigerator at 2 to $8{ }^{\circ} \mathrm{C}$ for a period of 2 hours for effective diffusion of test compounds and standards. Later, they were incubated at $37^{\circ} \mathrm{c}$ for 24 hours. The presence of definite zone of inhibition of any size around the cup indicated antibacterial activity. The diameter of the zone of inhibition was measured and recorded. It was done in triplicate and mean of zone of inhibition was calculated.

\section{In- vitro anthelmintic activity}

Table: 01 anthelmintic activity of ethanolic extracts of malvastrum cormandelianum leaves on earthworms

\begin{tabular}{|c|c|c|c|}
\hline Treatment & Concentration & $\begin{array}{c}\text { Time } \\
\text { taken for } \\
\text { Paralysis } \\
\text { (min) }\end{array}$ & $\begin{array}{c}\text { Time } \\
\text { taken } \\
\text { for } \\
\text { Death } \\
\text { (min) }\end{array}$ \\
\hline $\begin{array}{c}0.5 \% \\
\text { Sodium CMC } \\
\text { control }\end{array}$ & & & \\
\hline Albendazole & $10 \mathrm{mg} / \mathrm{ml}$ & $\begin{array}{c}2.90 \pm \\
2.90\end{array}$ & $\begin{array}{c}52.42 \pm \\
2.32\end{array}$ \\
\hline \multirow{3}{*}{ Ethanolic } & $100 \mathrm{mg} / \mathrm{ml}$ & $9.44 \pm 1.23$ & $33.02 \pm$ \\
extract & $50 \mathrm{mg} / \mathrm{ml}(\mathrm{T} 2)$ & $21.95 \pm$ & $42.66 \pm$ \\
& & 1.19 & 0.71 \\
\cline { 2 - 4 } & $25 \mathrm{mg} / \mathrm{ml}(\mathrm{T} 3)$ & $25.26 \pm$ & $54.51 \pm$ \\
& & 1.28 & 2.56 \\
\hline
\end{tabular}

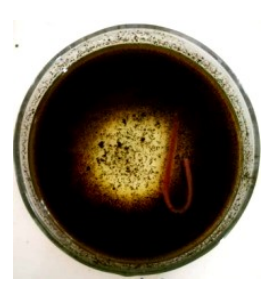

$100 \mathrm{mg} / \mathrm{ml}$

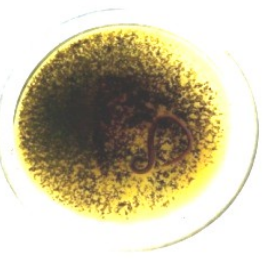

$50 \mathrm{mg} / \mathrm{ml}$

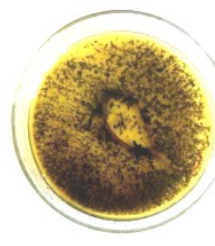

25 mg.ml

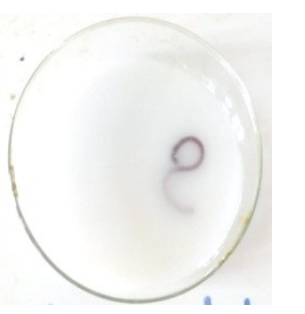

$10 \mathrm{mg} / \mathrm{ml}$ Albendazole

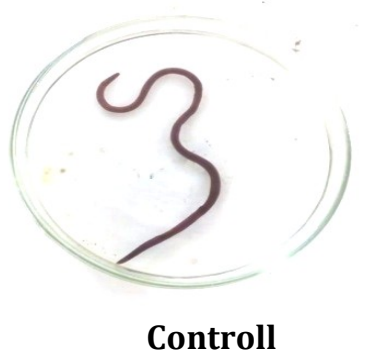

Controll
Fig: 01 Anthelmintic Activity of Ethanolic Extracts of Malvastrum Cormandelianum Leaves on Earthworms 


\section{In-Vitro antibacterial activity}

Table: 02 Antibacterial Activity Of Ethanolic Extracts Of Malvastrum Cormandelianum Leaves On Some Gram Positive \& Negative Bacteria

\begin{tabular}{|c|c|c|c|c|}
\hline \multirow{2}{*}{ Microorganism } & \multicolumn{4}{|c|}{ Zone of inhibition (mm) } \\
\cline { 2 - 5 } & $\mathbf{1 0 0} \mathbf{~} \mathbf{~ g / m l}$ & $\mathbf{2 0 0} \mathbf{~ m g} / \mathbf{m l}$ & $\mathbf{3 0 0} \mathbf{~ m g} / \mathbf{m l}$ & Gentamycin25 $\mathbf{H g} / \mathbf{m l}$ \\
\hline S.aureus & $15 \pm 0.21$ & $16 \pm 0.26$ & $17 \pm 0.15$ & $12 \pm 0.12$ \\
\hline B.subtilis & $11 \pm 0.62$ & $12 \pm 0.64$ & $13 \pm 0.21$ & $12 \pm 0.12$ \\
\hline E.Coli & $11 \pm 0.48$ & $12 \pm 0.48$ & $13 \pm 052$ & $12 \pm 0.12$ \\
\hline P.aerugenosa & $12 \pm 0.36$ & $13 \pm 0.39$ & $15 \pm 0.53$ & $12 \pm 0.12$ \\
\hline P.putida & $13 \pm 0.26$ & $13 \pm 0.52$ & $15 \pm 0.25$ & $12 \pm 0.12$ \\
\hline
\end{tabular}

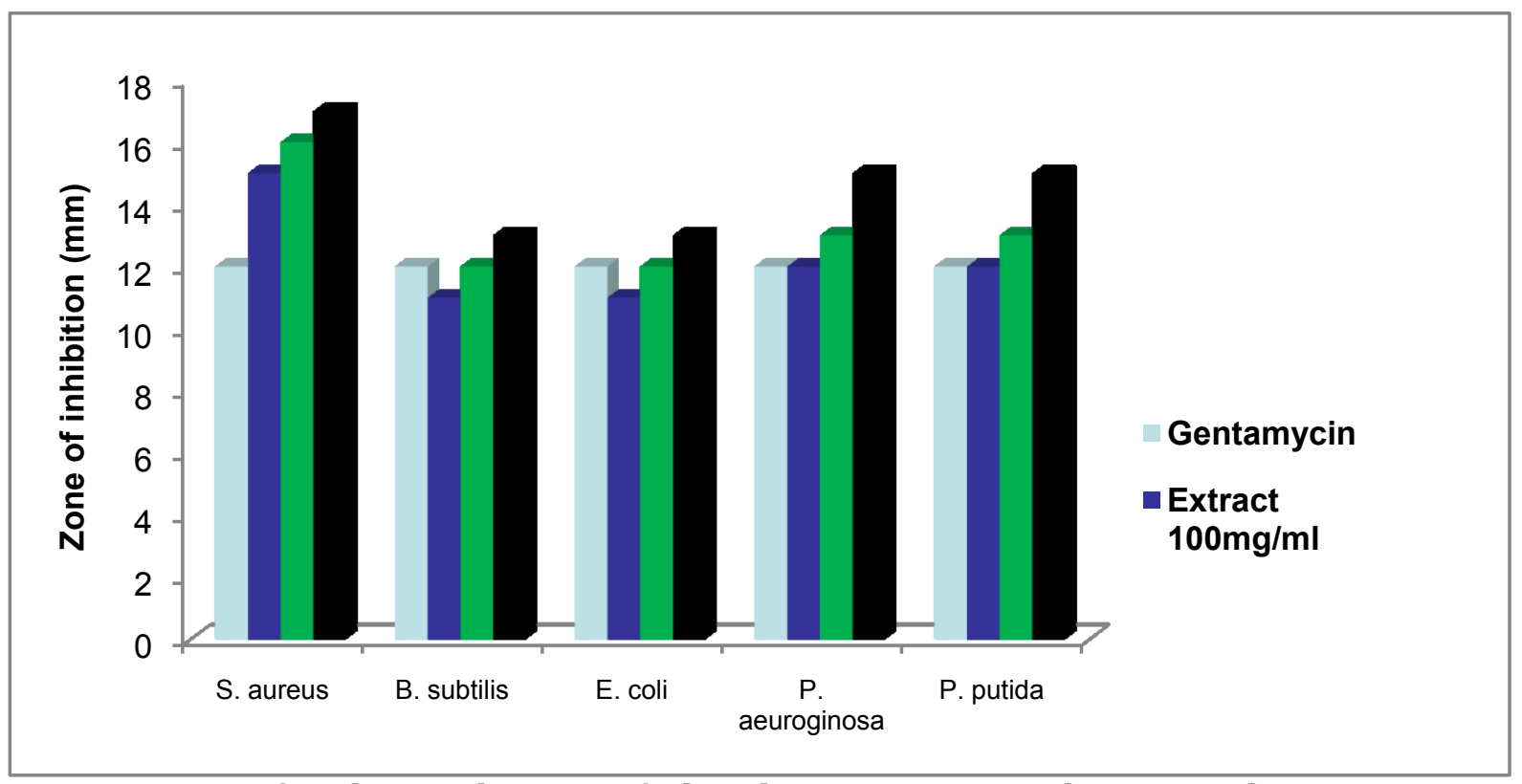

Fig: 02 comparision of antibacterial activity of ethanolic extracts against the some pathogenic organisms

\section{Discussion}

The results indicate that the ethanolic extract of Malvastrum coromandelianum showed the best anthelmintic activity at concentration of $100 \mathrm{mg} / \mathrm{ml}$ within $33 \mathrm{~min}$. The anthelmintic effect of extracts is comparable with that of the effect produced by the standard drug albendazole $(10 \mathrm{mg} / \mathrm{ml})$. All three concentrations have significant activity against earthworm with vary in duration of time. The antibacterial activity of leaves extract with different concentrations $100 \mathrm{mg} / \mathrm{ml}$, $300 \mathrm{mg} / \mathrm{ml}$ and500mg/ml was very well compared with standard reference drug Gentamycin $25 \mu \mathrm{g} / \mathrm{ml}$.The maximum zone of inhibition was observed in S.aureus at $500 \mathrm{mg} / \mathrm{ml}$ with of zone of inhibition $17 \mathrm{~mm}$ and next is S.aureus, the best antibacterial activity was observed against P.aerugenosa and P.putida with $15 \mathrm{~mm}$ of zone of inhibition. The extract has significant antibacterial activity against all microorganisms.

\section{Conclusion}

In present days, many microorganisms developing resistance to different chemical agent. So, it is necessary to develop new antibiotics. From the discussion, it is concluded that the ethanolic extract of Malvastrum coromandelianum leaves have Anthelmintic activity and Antibacterial activity against the adult Indian earthworm and some pathogenic microorganisms respectively.

\section{Acknowledgement}

The author is thankful to the management, principal and staff of SIMS College of Pharmacy for their support towards my project work.

\section{Funding}

No funding

\section{Author Contribution}

All authors are contributed equal work

\section{Conlfilict of intrest}

Authors are declre no conflict of intrest

\section{References}

1. McKean, Erin, ed. (2005), the New Oxford American Dictionary (2nd ed.), Oxford University Press, ISBN 978-0-19-517077-1. 
2. Dolores LL, Felipe A. Plants used by the Mexican Kickapoo Indians. Econ Bot. 1977; 31:340-57.

3. Sebastian MK, Bhandari MM. Medicoethno botany of Mount Abu, Rajasthan, India. J Ethnopharmacol. 1984; 12:223-30.

4. Andrade-Cetto A, Heinrich M. Mexican plants with hypoglycaemic effect used in the treatment of diabetes. J Ethnopharmacol. 2005; 99:325-48.

5. Khonsung P, Nantsupawat S, Jesadanont SN, Chantharateptawan V, Panthong A. Antiinflammatory and analgesic activities of water extract of Malvastrum coromandelianum (L.) Garcke. Thai J Pharmacol. 2006; 28:8-15.

6. Sittiwet C, Jesadanont S, Pongpech P, Naenna P, Pongsamart S. Antibacterial activity of MalvastrumcoromandelianumGracke against methicillin-sensitive and methicillin-resistant strains of Staphylococcus aureus. Curr Res Bacteriol. 2008; 1:42-5.

7. Jain P, Bansal D, Bhasin P, Anjali Antimicrobial activity and phytochemical screening of five wild plants against Escherichia coli, Bacillus subtilis and Staphylococcus aureus. J Pharm Res. 2010; 3:1260-2.

8. Ghosh T, Maity TK, Bose A, Dash GK. Athelmintic activity of Bacopamonierri. Indian J Nat Prodct. (2005); 21:16-9.

9. Siti NazrinaCamalxaman et al., In vitroAntimicrobial Activity of Vigna radiata(L) Wilzeck Extracts Against Gram Negative Enteric Bacteria, World Appl. Sci. J., 21 (10):1490-1494, 2013.

10. Hood, J. R., Wilkinson, J. M and Cavanagh, H. M.A.Evaluation of common antibacterial screening methods utilised in essential oil research. J Essential oil Res.,Nov/Dec (2003).

11. Aswar M, Aswar U, Watkar B, Vyas M, Wagh A, Gujar KN.Anthelmintic activity of Ficus benghalensis. International Journal of Green Pharmacy 2, 2008, 170-172.

12. Kinabakht $\mathrm{S}$ and Jahaniani F: Evaluation of the antibacterial activity of Tribulus terrestris $\mathrm{L}$. growing in Iran. Journal of Pharmacology Ther 2003; 2: 22-24. 